\title{
PENGARUH MODEL PEMBELAJARAN SCRAMBLE DENGAN MEDIA CROSSWORD PUZZLE TERHADAP MOTIVASI DAN HASIL BELAJAR KOGNITIF
}

\author{
Desi Dwi Sartika ${ }^{*}$, Rohani ${ }^{1}$ \\ ${ }^{1}$ Universitas Islam Negeri Sumatera Utara \\ *desidwisartika02@gmail.com
}

\begin{abstract}
ABSTRAK
Penelitian ini bertujuan untuk mengetahui pengaruh model pembelajaran scramble dengan media crossword puzzle terhadap motivasi dan hasil belajar kognitif biologi siswa. Motivasi belajar merupakan proses yang memberi semangat belajar, dorongan, dan perubahan tingkah laku dalam belajar. Hasil belajar merupakan skor yang menunjukkan tingkat pemahaman siswa. Penelitian ini dilakukan selama sekitar satu bulan. Jenis penelitian ini merupakan penelitian eksperimen dengan pretest-posttest control group design. Populasi berjumlah 60 siswa, sampel diambil menggunakan teknik simple random sampling. Sampel berjumlah 20 siswa kelas VIII-A sebagai kelas eksperimen dan 20 siswa kelas VIII-B sebagai kelas kontrol. Pengumpulan data menggunakan instrumen tes berupa pretest-posttest berbentuk pilihan berganda sebanyak 20 soal dan instrumen non tes berupa angket motivasi belajar yang meliputi delapan indikator motivasi belajar yang terdiri dari 20 soal. Data yang telah didapatkan dianalisis menggunakan uji t. Berdasarkan hasil analisis data pada motivasi belajar diperoleh $t_{\text {hitung }} \geq t_{\text {tabel }}$ yaitu $2,56 \geq 2,02$, sehingga hasil pengujian hipotesis dinyatakan $H_{0}$ ditolak dan $H_{a}$ diterima, dan pada hasil belajar kognitif siswa biologi diperoleh $t_{\text {hitung }} \geq t_{\text {tabel }}$ yaitu $16,58 \geq 2,02$, sehingga hasil pengujian hipotesis dinyatakan $H_{0}$ ditolak dan $H_{a}$ diterima. Maka dapat disimpulkan bahwa ada pengaruh model pembelajaran scramble dengan media crossword puzzle terhadap motivasi dan hasil belajar kognitif biologi siswa.
\end{abstract}

Kata Kunci: Crossword Puzzle, Hasil Belajar Kognitif, Motivasi Belajar, Scramble

\begin{abstract}
This study aims to determine the effect of scramble learning model with crossword puzzle media on motivation and cognitive learning outcomes of biology students. Learning motivation is a process that gives enthusiasm for learning, encouragement, and behavior change in learning. Learning outcomes are scores that indicate the level of student understanding. This research was conducted during one month. This type of research was an experimental research with pretest-posttest control group design. The population was 60 students with a sampling technique using simple random sampling. The sample was 20 students of VIII-A as experimental class and 20 students of VIII-B as control class. The data was obtained using the test instrument as pretest-posttest in 20 questions of multiple choices, and the non-test instrument test in the form of a learning motivation questionnaire which eight included indicators of learning motivation consisting of 20 questions. The data were analyzed by using $t$ test. Based on the

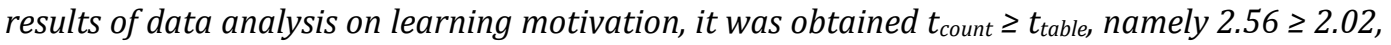
means that $H_{0}$ was rejected and $H_{a}$ was accepted, and on the cognitive learning outcomes of biology students, it was obtained $t_{\text {count }} \geq t_{\text {table, }}$ namely $16,58 \geq 2.02$, means that $H_{0}$ is rejected and $H_{a}$ is accepted. So it can be concluded that there is an effect of the Scramble learning model with Crossword Puzzle media on the motivation and cognitive learning outcomes of biology students.
\end{abstract}

Keywords: Crossword Puzzle, Cognitive Learning Outcome, Learning Motivation, Scramble

\section{PENDAHULUAN}

Pendidikan merupakan sarana dalam proses perubahan budaya untuk memajukan kebudayaan masyarakat dan bangsa. Perubahan budaya diharapkan dapat memenuhi tuntutan pengembangan potensi siswa secara maksimal, baik potensi intelektual, spiritual, sosial, moral, maupun kesenian. Pendidikan akan diberikan 
melalui bimbingan, pengajaran, dan latihan sebagai kegiatan proses pendidikan. Sehingga melalui kegiatan tersebut akan menjamin perkembangan hidup suatu individu dan masyarakat, yang pada akhirnya terbentuklah kedewasaan atau kepribadian seutuhnya (Syafaruddin et al., 2016).

Menurut Ki Hajar Dewantara Pendidikan berarti upaya untuk memajukan perkembangan budi pekerti (kekuatan batin), pikiran (intelektual), dan jasmani siswa. Siswa hanya dapat berkembang ketika pendidikan dilakukan tanpa paksaan dan tanpa perintah (Marzuki dan Khanifah, 2016). Pendidikan yang ideal adalah pendidikan yang tidak hanya transfer of knowledge tetapi juga transfer of value. Dengan demikian, pendidikan tidak hanya menghasilkan siswa beratribut "robot cerdas", tetapi juga siswa dengan karakter yang baik. Dalam hal ini, Ki Hajar Dewantara lebih menekankan pada pendidikan budi pekerti atau pendidikan karakter sebagai pendidikan yang ideal. Pada tahap ini, guru dan sistem pendidikan memiliki andil yang signifikan. (Marzuki \& Khanifah, 2016).

Sesuai kemajuan dan tuntutan zaman, pendidik wajib mempunyai kemampuan mengetahui siswa menggunakan aneka macam keunikannya, supaya dapat membantu mereka saat menghadapi kesulitan belajar. Pendidik juga wajib berpacu pada pembelajaran, dengan cara memberikan kemudahan belajar bagi semua siswa, supaya bisa menyalurkan potensinya secara optimal. Dalam hal ini, pendidik wajib kreatif, profesional dan menyenangkan (Tanjung, 2016).

Pendidikan diambil dari bahasa Yunani yaitu dari kata "pedagogik" yang berarti ilmu mendidik anak. Menurut bangsa Romawi, pendidikan sebagai educare yang berarti melahirkan dan mendidik, di mana potensi anak sejak dilahirkan di dunia dapat terwujud.

Sebagaimana dijelaskan dalam QS. AnNahl, 16: 78, mengenai pendidikan sebagai pengembangan potensi manusia, Allah SWT berfirman:

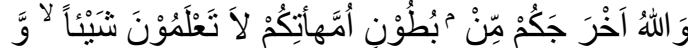

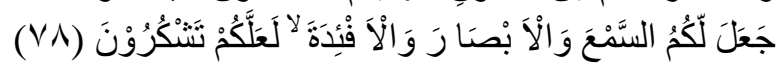

Artinya: "Dan Allah mengeluarkan kamu dari perut ibumu dalam keadaan tidak mengetahui sesuatu apapun, dan Dia memberimu pendengaran, penglihatan, dan hati nurani, agar kamu bersyukur." (Kementerian Agama RI, 2015).

Sesuai dengan firman Allah di atas bahwa ketika manusia baru dilahirkan dari perut ibunya, mereka tidak memiliki pengetahuan apapun. Kemudian, pada saat itu Allah menunjukkan kepada mereka sebagaimana ditunjukkan oleh apa yang telah Dia putuskan, misalnya melalui proses pendengaran, penglihatan dan mata hati sebagai potensi penciptaan pengaturan untuk mencari ilmu pengetahuan, sehingga kita percaya kepada-Nya berdasarkan keyakinan dan mensyukuri setiap nikmat-Nya.

Biologi ialah ilmu alam tentang tentang makhluk hidup atau penyelidikan tentang kehidupan. Biologi mengkaji berbagai persoalan yang berkaitan dengan fenomena kehidupan makhluk hidup pada tingkat organisasi kehidupan dan tingkat interaksinya dengan faktor lingkungan (Hasan, 2017).

Peneliti melakukan observasi dan wawancara pada guru mata pelajaran IPA di MTs. Model pembelajaran yang digunakan bersifat teacher centered approach, siswa kurang aktif dalam kelompok belajar biologi kurangnya penggunaan strategi dan media pembelajaran yang kreatif dan menarik, sehingga dapat berdampak pada motivasi, keaktifan dan kreativitas siswa yang akan mengakibatkan hasil belajar siswa menjadi rendah. Hal ini perlu adanya motivasi belajar yang tinggi untuk mencapai hasil belajar yang baik, karena motivasi dapat mempengaruhi hasil belajar kognitif biologi siswa.

Motivasi diartikan sebagai energi yang mengalami perubahan dengan ditandai oleh dorongan afektif di dalam diri seseorang untuk mencapai tujuan (Majid, 2017). Hasil belajar merupakan segala perilaku siswa sebagai 


\section{Jurnal Biolokus: Jurnal Penelitian Pendidikan Biologi dan Biologi Vol.4(1)}

dampak setelah melewati proses belajar (Nurmawati, 2016).

Motivasi sebagai salah satu faktor internal output belajar yang berfungsi untuk menciptakan, mendasari, mengarahkan perlakuan pembelajaran. Motivasi bisa menentukan apakah dapat diterima dalam mencapai tujuan, sehingga semakin diperhatikan inspirasi maka semakin menonjol prestasi belajarnya. Seseorang yang sangat energik akan melakukan upaya yang baik, terlihat teguh dan tidak menyerah tanpa masalah. Maka, dengan adanya usaha yang maksimal dan terutama bergantung pada motivasi, seseorang yang belajar akan menghasilkan pencapaian besar. Dalam latihan belajar, inspirasi sangat penting, mengingat seseorang yang tidak memiliki inspirasi dalam belajar tidak akan melakukan latihan belajar. (Sinaga et al., 2017).

Model pembelajaran kooperatif adalah suatu model pembelajaran yang menerapkan sistem belajar dalam kelompok-kelompok kecil yang berjumlah 4-6 orang dengan bekerja sama sehingga dapat mendorong siswa lebih semangat dalam belajar (Tanjung, 2018).

Dalam QS. An-Nahl, 16: 125, mengenai berdiskusi dalam kelompok belajar, Allah SWT berfirman:

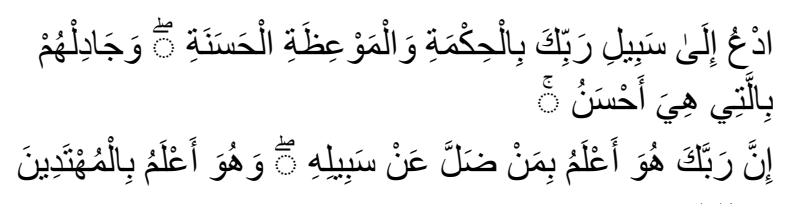

( I ro)

Artinya: "Serulah (manusia) kepada jalan Tuhanmu dengan hikmah dan pelajaran yang baik dan berdebatlah mereka dengan cara yang baik. Sesungguhnya Tuhanmu Dialah yang lebih mengetahui tentang siapa yang tersesat dari jalan-Nya dan Dialah yang lebih mengetahui orang-orang yang mendapat petunjuk." (Kementerian Agama RI, 2015).

Berdasarkan QS. An-Nahl, 16: 125 di atas bahwa pembelajaran kooperatif tepat untuk meningkatkan kualitas interaksi antar siswa melalui cara berdiskusi dengan baik dalam kelompok belajar. Sehingga memperoleh pengertian yang lebih jelas, mempersiapkan dan menyelesaikan keputusan secara bersamasama.

Ada banyak jenis pembelajaran kooperatif salah satunya scramble. scramble merupakan suatu metode mengajar dengan membagikan lembar soal dan lembar jawaban yang disertai dengan alternatif jawaban, namun dengan susunan yang acak, jadi siswa bertugas mengoreksi (membolak-balik huruf) jawaban tersebut sehingga menjadi jawaban yang tepat/benar (Mukrimah, 2014).

Pembelajaran akan lebih inovatif dan memudahkan siswa untuk dibantu oleh suatu media, khususnya media crossword puzzle. crossword puzzle atau teka-teki silang merupakan salah satu media pembelajaran berupa permainan sebagai sarana untuk menumbuhkan berbagai kata dan pemanfaatan ejaan yang benar. (Arofah \& Efendi, 2015).

Sebagai perbandingan, Parinding \& Lumbu (2015) menggunakan model pembelajaran scramble, namun variabel terikat dari penelitian terdahulu yaitu minat dan hasil belajar. Materi yang diajarkan yaitu struktur dan fungsi sel. Metode yang digunakan yaitu one-group pretestposttest design. Adapun instrumen penelitian yang digunakan dalam penelitian ini berupa tes hasil belajar, LKS dan proses yang diberikan kepada siswa yang berada dalam kelas eksperimen, di mana tes hasil belajar dibuat oleh peneliti dalam bentuk pilihan ganda. Sedangkan soal essay harus dijawab oleh tiap kelompok kemudian dipresentasikan, setelah itu menjawab soal dalam bentuk model pembelajaran scramble. Dalam uji coba instrumen tes untuk keperluan pengumpulan data, penulis dapat menguji validitas, reliabilitas, tingkat kesukaran dan daya beda. Setelah itu, berdasarkan pengumpulan data, dilakukan uji regresi menggunakan SPSS 16.0 for windows. Diperoleh hasil penelitian yaitu: (1) Ada pengaruh model pembelajaran kooperatif tipe scramble terhadap minat belajar, di mana $t_{\text {hitung }}(2,366)>t_{\text {tabel }}(1,697)$ maka $H_{0}$ ditolak dan $\mathrm{H}_{\mathrm{a}}$ diterima; (2) Ada pengaruh model pembelajaran kooperatif tipe scramble terhadap hasil belajar, di mana thitung $(3,093)>t_{\text {tabel }}$ 
$(1,697)$ maka $\mathrm{H}_{0}$ ditolak dan $\mathrm{H}_{\mathrm{a}}$ diterima. Hal ini menunjukkan bahwa pembelajaran biologi dengan menerapkan model pembelajaran kooperatif tipe scramble lebih efektif dari pada model pembelajaran konvensional.

Berdasarkan adanya permasalahan yang telah ditemukan, model pembelajaran scramble dengan media crossword puzzle diharapkan dapat memberi motivasi dan meningkatkan hasil belajar kognitif siswa pada mata pelajaran biologi, karena belajar sambil bermain itu menarik dan mudah diserap oleh siswa, sehingga memungkinkan siswa lebih aktif. Adapun tujuan dari penelitian ini adalah untuk mengetahui pengaruh model pembelajaran scramble dengan media crossword puzzle terhadap motivasi belajar biologi dan mengetahui pengaruh model pembelajaran scramble dengan media crossword puzzle terhadap hasil belajar kognitif biologi siswa.

\section{METODE}

Penelitian ini dilaksanakan di kelas VIII MTs selama sekitar satu bulan. Jenis penelitian ini merupakan penelitian eksperimen menggunakan pretest-posttest control group design (Tabel 1) (Arieska \& Herdiani, 2018).

Tabel 1. Pretest-posttest control group design

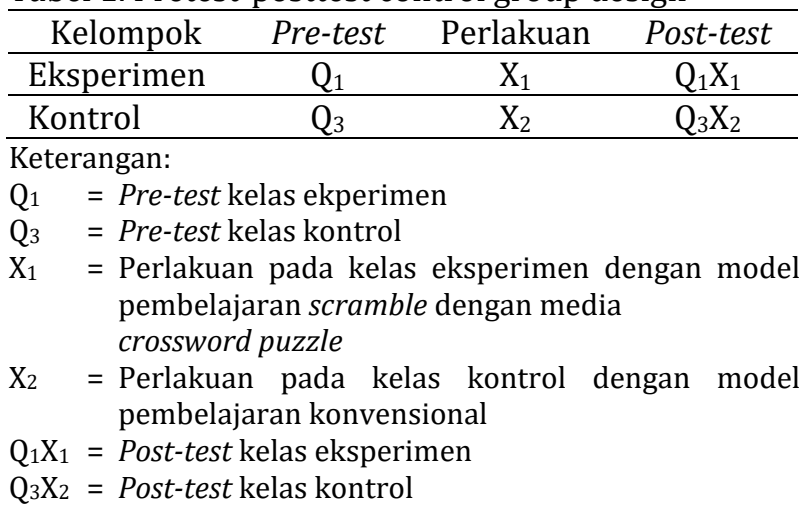

Populasi merupakan seluruh siswa kelas VIII MTs YPI Subulul Huda yang berjumlah 60 siswa. Teknik pengambilan sampel menggunakan simple random sampling. Penerapan teknik sampling pada penelitian ini dilakukan dengan cara undian (memilih kertas secara acak). Sampel berjumlah 40 siswa yang terdiri atas 20 siswa kelas VIII-A sebagai kelas eksperimen yang diberi perlakuan model pembelajaran scramble dengan media crossword puzzle dan kelas VIII-B yang berjumlah 20 siswa sebagai kelas kontrol dengan model pembelajaran konvensional.

Instrumen pengumpulan data menggunakan tes, berupa pretest-posttest berbentuk pilihan berganda yang berjumlah 20 soal dan non tes berupa angket motivasi belajar yang meliputi 8 indikator motivasi belajar yang terdiri dari 20 soal. Sebelum melakukan penelitian, terlebih dahulu dilakukan uji validitas instrumen tes kepada validator dan siswa di luar sampel, lalu data dihitung dengan uji validitas, uji reliabilitas, uji tingkat kesukaran, dan uji daya beda sehingga instrumen tes layak digunakan. Setelah semua data terkumpul, maka selanjutnya data dianalisis menggunakan analisis statistik seperti uji normalitas dan uji homogenitas, serta uji hipotesis dengan ketentuan jika $t_{\text {hitung }} \leq t_{\text {tabel }}$, maka $\mathrm{H}_{0}$ diterima dan $\mathrm{H}_{a}$ ditolak. Jika $\mathrm{t}_{\text {hitung }} \geq$ $t_{\text {tabel, }}$ maka $\mathrm{H}_{0}$ ditolak dan $\mathrm{H}_{\mathrm{a}}$ diterima. Dengan taraf signifikan $\alpha=0,05 \quad$ (5\%). Untuk mengetahui hasil perhitungan datanya yaitu menggunakan program analisis statistik SPSS Statistics 20.

\section{HASIL DAN PEMBAHASAN \\ Deskripsi Data Hasil Penelitian}

Data di bawah ini merupakan nilai statistik deskriptif hasil pretest dan posttest pada kelas eksperimen dan kelas kontrol (Tabel 2).

Tabel 2. Nilai statistik deskriptif hasil pre-test dan post-test pada kelas eksperimen dan kelas kontrol

\begin{tabular}{lcccc}
\hline & N & Min & Max & Mean \\
\hline $\begin{array}{l}\text { Pre-test Kelas } \\
\text { Eksperimen }\end{array}$ & 20 & 60 & 75 & 66.25 \\
\hline $\begin{array}{l}\text { Post-test Kelas } \\
\text { Eksperimen }\end{array}$ & 20 & 80 & 95 & 89.25 \\
\hline Pre-test Kelas Kontrol & 20 & 55 & 70 & 60.25 \\
\hline Post-Test Kelas Kontrol & 20 & 55 & 70 & 62.50 \\
\hline Valid N & 20 & & & \\
\hline
\end{tabular}

\section{Keterangan:}

$\mathrm{N} \quad=$ Jumlah soal $\quad$ Min = Nilai terendah

Mean $=$ Nilai rata-rata $\quad$ Max $=$ Nilai tertinggi

Hasil dan rata-rata pretest dan posttest (Gambar 1) menunjukkan bahwa nilai rata-rata posttest hasil belajar siswa kelas eksperimen 
lebih tinggi dari hasil belajar siswa kelas kontrol, yaitu pada kelas eksperimen diperoleh nilai rata-rata mencapai 89,25 dan pada kelas kontrol diperoleh nilai rata-rata mencapai 62,50 yang masih di bawah Kriteria Ketuntasan Minimum (KKM). Hal ini menunjukkan bahwa hasil belajar biologi siswa dapat meningkat dengan menggunakan model pembelajaran scramble dengan media crossword puzzle daripada pembelajaran konvensional pada materi sistem respirasi.

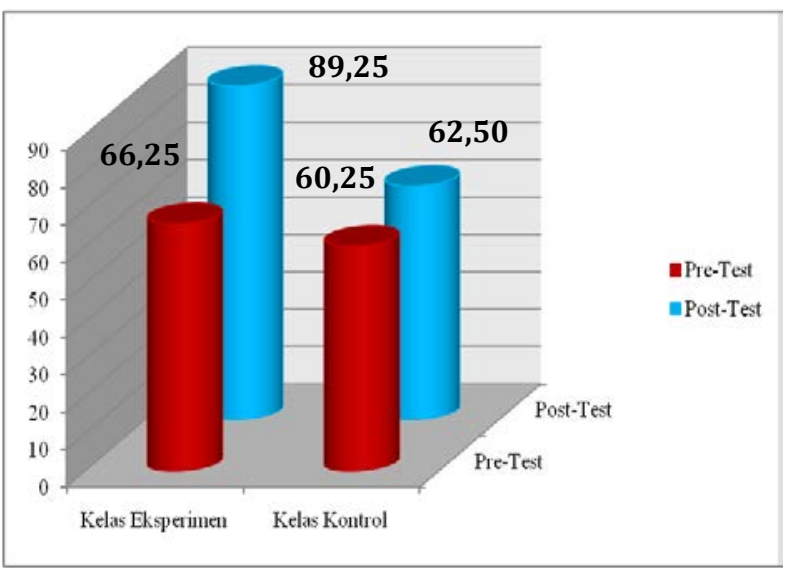

Gambar 1. Skor rata-rata pretest dan posttest

Hasil analisis terhadap data mengenai motivasi belajar siswa di kelas eksperimen dipersentasekan dan didapatkan hasil sebesar 63,95\%. Sedangkan motivasi belajar siswa di kelas kontrol dianalisis dengan menggunakan rumus persentase dan diperoleh hasil sebesar $52,15 \%$. Perbandingan persentase nilai ratarata motivasi belajar siswa pada kelas ekperimen dan kelas kontrol dapat dilihat pada Gambar 2.

Perbandingan tersebut menunjukkan bahwa nilai rata-rata motivasi belajar siswa pada kelas eksperimen secara signifikan lebih tinggi dari kelas kontrol dengan selisih persentase $11,8 \%$. Hal ini terlihat dari perolehan nilai rata-rata motivasi belajar siswa pada kelas eksperimen yaitu $63,95 \%$ termasuk katogori tinggi (termotivasi), sedangkan pada kelas kontrol yaitu 52,15\% termasuk kategori sedang.

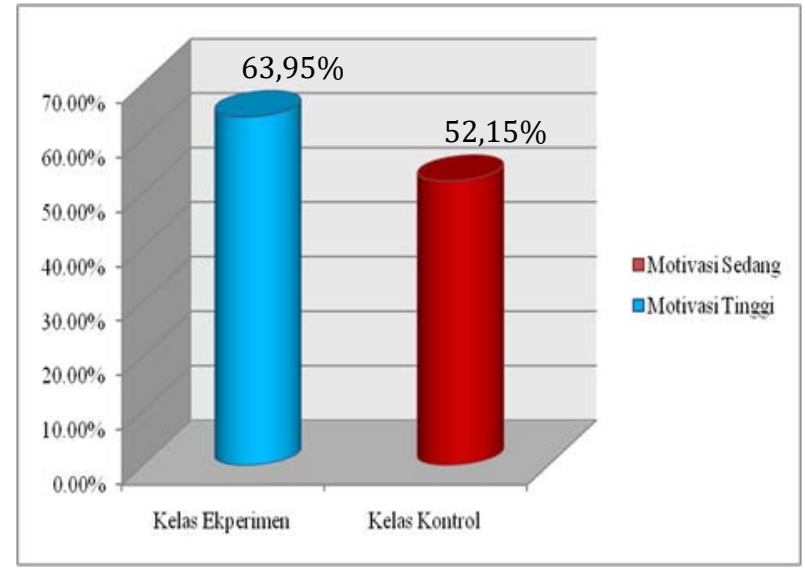

Gambar 2. Perbandingan nilai rata-rata motivasi belajar biologi siswa pada kelas eksperimen dan kelas kontrol

\section{Uji Normalitas}

Tabel 3. Hasil uji normalitas angket

\begin{tabular}{clccc}
\hline \multirow{2}{*}{$\begin{array}{c}\text { Skor } \\
\text { Total }\end{array}$} & \multicolumn{1}{c}{ Kelas } & \multicolumn{3}{c}{ Kolmogorov-Sminov $^{a}$} \\
\cline { 2 - 5 } Motivas & Eksperime & Statistic & df & Sig. \\
i Belajar & $\mathrm{n}$ & .142 & 20 & .200 \\
\cline { 2 - 5 } & Kontrol & .169 & 20 & .154 \\
\hline
\end{tabular}

Berdasarkan Tabel 3, nilai total motivasi belajar kelas eksperimen diperoleh sig.hitung $=$ $0,200(0,200 \geq 0,05)$ dan skor total motivasi belajar kelas kontrol diperoleh sig.hitung $=0,154$ $(0,154 \geq 0,05)$. Hal ini sesuai dengan ketentuan uji normalitas bahwa data tersebut berdistribusi normal.

Tabel 4. Hasil uji normalitas soal

\begin{tabular}{|c|c|c|c|c|}
\hline \multirow{6}{*}{$\begin{array}{l}\text { Hasil } \\
\text { Belajar } \\
\text { Kognitif } \\
\text { Siswa }\end{array}$} & \multirow{2}{*}{ Kelas } & \multicolumn{3}{|c|}{ Kolmogorov-Sminov ${ }^{a}$} \\
\hline & & Statistic & Df & Sig. \\
\hline & $\begin{array}{l}\text { Pretest } \\
\text { Eksperimen }\end{array}$ & .202 & 20 & .032 \\
\hline & $\begin{array}{l}\text { Posttest } \\
\text { Eksperimen }\end{array}$ & .205 & 20 & .028 \\
\hline & $\begin{array}{l}\text { Pretest } \\
\text { Kontrol }\end{array}$ & .220 & 20 & .012 \\
\hline & $\begin{array}{l}\text { Posttest } \\
\text { Kontrol } \\
\end{array}$ & .201 & 20 & .033 \\
\hline
\end{tabular}

Berdasarkan Tabel 4 bahwa hasil pretest dan posttest kelas eksperimen diperoleh sig.hitung $=0,32(0,32 \geq 0,05)$, dan kelas kontrol sig.hitung $=$ $0,12(0,12 \geq 0,05)$, pada posttest kelas eksperimen di peroleh sig.hitung $=0,28(0,28 \geq$ $0,05)$, dan kelas kontrol sig.hitung $=0,33(0,33 \geq$ 0,05). Hal ini sesuai dengan ketentuan uji normalitas bahwa data tersebut berdistribusi normal. 
Jurnal Biolokus: Jurnal Penelitian Pendidikan Biologi dan Biologi Vol.4(1)

\section{Uji Homogenitas}

Tabel 5. Hasil uji homogenitas angket

\begin{tabular}{|c|c|c|c|c|c|}
\hline \multirow{2}{*}{$\begin{array}{c}\text { Motivasi } \\
\text { Belajar }\end{array}$} & & $\begin{array}{c}\text { Levene } \\
\text { Statistic }\end{array}$ & df1 & df2 & Sig. \\
\hline & $\begin{array}{c}\text { Based } \\
\text { on Mean }\end{array}$ & .300 & 1 & 37 & .587 \\
\hline
\end{tabular}

Berdasarkan Tabel 5 dapat dilihat bahwa hasil angket pada kelas eksperimen dan kelas kontrol sebesar 0,587 yang berarti 0,587 $\geq 0,05$. Sesuai dengan ketentuan uji homogenitas, data bersifat homogen (mempunyai variansi yang sama).

Tabel 6. Hasil uji homogenitas soal

\begin{tabular}{|c|c|c|c|c|c|}
\hline $\begin{array}{c}\text { Hasil } \\
\text { Belajar }\end{array}$ & & $\begin{array}{c}\text { Levene } \\
\text { Statistic }\end{array}$ & df1 & $\mathrm{df} 2$ & Sig. \\
\hline $\begin{array}{l}\text { Kognitif } \\
\text { Siswa }\end{array}$ & $\begin{array}{c}\text { Based } \\
\text { on Mean }\end{array}$ & .320 & 1 & 38 & .575 \\
\hline
\end{tabular}

Berdasarkan Tabel 6 dapat dilihat bahwa hasil posttest pada kelas eksperimen dan kelas kontrol sebesar 0,575 yang berarti $0,575 \geq 0,05$. Sesuai dengan ketentuan uji homogenitas bahwa data bersifat homogen (mempunyai variansi yang sama).

\section{Uji Hipotesis}

Tabel 7. Hasil uji hipotesis angket

\begin{tabular}{cccccc}
\hline Nilai & Kelas & $\begin{array}{c}\overline{\boldsymbol{X}} \\
(\mathrm{Mean})\end{array}$ & $\begin{array}{c}\text { Nilai } \\
\mathrm{t}_{\text {hitung }}\end{array}$ & $\begin{array}{c}\text { Nilai } \\
\mathrm{t}_{\text {tabel }}\end{array}$ & $\begin{array}{c}\text { Kesim- } \\
\text { pulan }\end{array}$ \\
\hline \multirow{2}{*}{ Angket } & $\begin{array}{l}\text { Ekspe- } \\
\text { rimen }\end{array}$ & 63,95 & 2,56 & 2,02 & $\begin{array}{l}\mathrm{H}_{\mathrm{a}} \\
\text { diterima }\end{array}$ \\
\cline { 2 - 3 } & Kontrol & 52,15 & & $\begin{array}{l}\mathrm{H}_{0} \\
\text { ditolak }\end{array}$ \\
\hline
\end{tabular}

Berdasarkan Tabel 7, dilakukan perhitungan uji $\mathrm{t}$ dan diperoleh nilai rata-rata angket siswa kelas eksperimen lebih tinggi jika dibandingkan dengan nilai rata-rata posttest siswa kelas kontrol. Hasil analisis uji t diambil dari skor total data angket, maka diperoleh $t_{\text {hitung }}$ $\geq t_{\text {tabel }}$ yaitu $2,56 \geq 2,02$, sehingga hasil pengujian hipotesis dinyatakan $\mathrm{H}_{0}$ ditolak dan $\mathrm{H}_{\mathrm{a}}$ diterima.

Tabel 8. Hasil uji hipotesis soal

\begin{tabular}{|c|c|c|c|c|c|}
\hline Nilai & Kelas & $\begin{array}{c}\overline{\boldsymbol{X}} \\
\text { (Mean) }\end{array}$ & $\begin{array}{l}\text { Nilai } \\
t_{\text {hitung }}\end{array}$ & $\begin{array}{l}\text { Nilai } \\
t_{\text {tabel }}\end{array}$ & $\begin{array}{l}\text { Kesim- } \\
\text { pulan }\end{array}$ \\
\hline \multirow{2}{*}{$\begin{array}{l}\text { Post- } \\
\text { test }\end{array}$} & $\begin{array}{l}\text { Ekspe- } \\
\text { rimen }\end{array}$ & 66,25 & \multirow{2}{*}{16,58} & \multirow{2}{*}{2,02} & $\begin{array}{l}\mathrm{H}_{\mathrm{a}} \\
\text { diterima }\end{array}$ \\
\hline & Kontrol & 60,25 & & & $\begin{array}{l}\mathrm{H}_{0} \\
\text { ditolak }\end{array}$ \\
\hline
\end{tabular}

Berdasarkan Tabel 8, dilakukan perhitungan uji $t$ dan diperoleh nilai rata-rata posttest siswa kelas eksperimen lebih tinggi jika dibandingkan dengan nilai rata-rata posttest siswa kelas kontrol. Hasil analisis uji t diambil dari nilai rata-rata posttest yaitu $16,58 \geq 2,02$, sehingga hasil pengujian hipotesis dinyatakan $\mathrm{H}_{0}$ ditolak dan $\mathrm{H}_{\mathrm{a}}$ diterima.

Berdasarkan hasil analisis data, motivasi belajar siswa pada kelas ekperimen memiliki motivasi belajar yang jauh lebih tinggi dibandingkan dengan kelas kontrol yang hanya diajarkan menggunakan model pembelajaran konvensional. Begitu pula dengan hasil belajar kognitif biologi siswa meningkat pada kelas ekperimen. Hal ini dipengaruhi oleh strategi pembelajaran yang menggunakan model pembelajaran scramble dengan media crossword puzzle.

Scramble merupakan salah satu jenis pembelajaran kooperatif. Kooperatif yaitu gerakan belajar siswa yang dibentuk dalam perkumpulan-perkumpulan kecil untuk ikut mengatasi masalah dalam tugas yang diberikan dengan bekerja sama dan berbagi pemikiran (Bailang et al., 2017). Scramble adalah permainan kata yang tidak teratur yang menekankan partisipasi siswa dalam suatu kelompok, untuk membangun gerakan dan memberikan pemahaman ide-ide pembelajaran, dan memudahkan siswa untuk menangani suatu masalah (Hadi et al., 2017). Menurut Hafsah (2017), scramble adalah metode mengajar dengan menunjukkan lembar soal dan lembar jawaban yang disertai dengan jawaban-jawaban pilihan yang diberikan, siswa dituntut untuk menemukan jawaban dan jawaban dari permasalahan yang ada.

Pembelajaran akan lebih kreatif jika dibantu dengan sebuah media. Adanya bantuan media crossword puzzle, maka siswa dapat melihat dan mempelajari huruf-huruf jawaban dengan cara yang berbeda, yaitu dari segi warna, bentuk dan penyusunan letak huruf jawaban pada media. Crossword puzzle mampu menjadi daya tarik siswa untuk lebih giat belajar. Hal tersebut menjadi salah satu faktor 
pelengkap dan pendukung meningkatnya motivasi dan hasil belajar kognitif biologi siswa.

Crossword puzzle (teka-teki silang) adalah permainan bahasa dimana kita mengisi kotak dengan huruf untuk membentuk kata yang dapat dibaca dengan teliti, baik dalam arah ke atas atau secara merata. Menyediakan pertanyaan tes sebagai teka-teki silang sebagai kata yang mengandung komponen permainan dalam pembelajaran akan menarik, menginspirasi\&minat siswa (Akbar et al., 2018).

Adapun tahapan dalam mengaplikasikan model pembelajaran scramble dengan media crossword puzzle menurut Huda (2018), yaitu ada sembilan tahap. Pertama, yaitu guru menyajikan materi ajar sesuai topik kepada siswa. Tahap ini merupakan tahapan penyampaian pokok-pokok materi pembelajaran sebelum siswa membentuk kelompok belajar, agar siswa mendapat pemahaman.

Kedua, yaitu guru membagi kelompok belajar kepada siswa. Ketiga, yaitu guru membagikan lembar kerja berupa kartu soal dan kartu jawaban yang diacak susunannya. Keempat, yaitu guru memberi penjelasan mengenai model dan media pembelajaran yang akan diajarkan dan durasi tertentu untuk pengerjaan soal.

Kelima, yaitu siswa mengerjakan soal berdasarkan waktu yang telah ditentukan guru dengan saling membantu di dalam kelompoknya. Di tahap ini guru membimbing kelompok-kelompok belajar pada saat mereka mengerjakan tugas mereka.

Keenam, yaitu siswa mencari jawaban yang tepat untuk setiap soal yang mereka kerjakan dan memasangkannya pada kartu soal. Ketujuh, yaitu guru mengecek durasi waktu sambil memeriksa pekerjaan siswa, sembari memantau kegiatan siswa selama proses pengerjaan. Kedelapan, yaitu jika waktu pengerjaan soal sudah habis, siswa wajib mengumpulkan lembar jawaban kepada guru, baik yang sudah selesai maupun belum selesai.

Kesembilan, yaitu guru melakukan penilaian. Penilaian dilakukan berdasarkan seberapa cepat siswa menjawab soal dan seberapa banyak soal yang dijawab dengan benar.

Tahapan-tahapan tersebut dapat dilihat adanya peran aktif antara guru dan siswa, khususnya pada tahapan kelima dan keenam yang berkontribusi besar pada peningkatan motivasi dan hasil belajar kognitif siswa. Pada tahap kelima, siswa mengerjakan soal berdasarkan waktu yang telah ditentukan guru dengan saling membantu di dalam kelompoknya. Di tahap ini guru membimbing kelompok-kelompok belajar pada saat mereka mengerjakan tugas mereka. Dan tahap keenam, siswa mencari jawaban yang tepat untuk setiap soal yang mereka kerjakan dan memasangkannya pada kartu soal.

Pada kedua tahapan tersebut terlihat bahwa proses belajar mengajar di kelas eksperimen berjalan dengan kondusif, siswa menjadi aktif dan lebih semangat, siswa mampu berpartisipasi dalam kegiatan pembelajaran dengan saling bekerja sama, belajar bersama dengan teman dan bertanggung jawab dengan tugas yang telah diberikan, serta terjalinnya komunikasi antara siswa dengan siswa, maupun siswa dengan peneliti. Hal ini dikarenakan siswa dapat belajar dengan santai, namun tetap konsentrasi, sehingga timbul rasa senang dan termotivasi selama proses pembelajaran biologi berlangsung. Jika motivasi belajar siswa meningkat, maka hasil belajar kognitif siswa juga meningkat.

Motivasi dapat mempengaruhi hasil belajar siswa, diidentikkan dengan model pembelajaran bermanfaat tipe scramble menghadirkan beberapa permainan yang dapat membuat siswa dalam kelompoknya lebih dinamis dalam menyelesaikan jawaban atas pertanyaan yang diajukan. Seperti halnya menghilangkan kepenatan siswa dalam belajar, siswa juga terinspirasi untuk belajar dan dapat lebih mengembangkan hasil belajarnya (Sumartono \& Normalina, 2015)

Menurut Hafsah (2017), Pembelajaran kooperatif tipe scramble adalah sebuah metode yang menggunakan penekanan latihan soal berupa permainan yang dikerjakan secara berkelompok. Dalam metode pembelajaran ini 
perlu adanya kerja sama antar anggota kelompok untuk saling membantu teman sekelompok dapat berpikir kritis sehingga dapat lebih mudah dalam mencari penyelesaian soal.

Adapun keunggulan dari model pembelajaran scramble yaitu siswa ketika belajar mampu mencari ide atau mengatasi masalah di lingkungan yang indah. Siklus belajar membuat siswa terdorong untuk belajar dan saling membantu, latihan pembelajaran akan lebih bermakna dan menyenangkan, dengan tujuan agar hasil belajar siswa dapat meningkat (Hafsah, 2017).

Selain itu, media crossword puzzle sebagai pelengkap dalam pengaplikasian strategi pembelajaran juga memiliki keunggulan, diantaranya yaitu: belajar ternyata sangat menarik dan menyenangkan, karena siswa dikaitkan dengan permainan edukatif; siap menumbuhkan motivasi siswa untuk mencoba melihat lebih banyak kata karena komponen tantangan yang membuat minat; dan dapat mempertajam daya pikir dan melatih keteguhan siswa (Rosady, 2017).

Setiap guru membutuhkan interaksi belajar yang dilakukan dengan baik, menyenangkan dan lebih fokus pada siswa, berarti bahwa siswa harus lebih aktif dalam siklus pembelajaran. Pencapaian tujuan instruktif dikendalikan oleh siklus belajar yang dialami siswa. Interaksi pembelajaran yang dapat menumbuhkan kemampuan siswa adalah siklus belajar dengan menerapkan model pembelajaran yang kreatif dan inovatif, serta dilengkapi dengan media pembelajaran yang menarik, sehingga siswa terdorong dan berperan aktif dalam latihanlatihan pembelajaran yang dikoordinasikan oleh guru. Dengan adanya model pembelajaran scramble dengan media crossword puzzle ini maka siswa akan memahami solusi dari permasalahan yang diberikan dan penguasaan konsep terpenuhi, sehingga siswa termotivasi dalam mengikuti proses pembelajaran dan hasil belajar kognitif biologi siswa meningkat.

\section{PENUTUP}

Berdasarkan analisis data dari hasil penelitian, maka dapat disimpulkan bahwa ada pengaruh model pembelajaran scramble dengan media crossword puzzle terhadap motivasi belajar biologi siswa. Motivasi belajar pada kelas ekperimen lebih tinggi daripada kelas kontrol. Hal ini dapat dibuktikan dari hasil analisis uji t yang diambil dari skor total data angket, sehingga hasil pengujian hipotesis dinyatakan $\mathrm{H}_{0}$ ditolak dan $\mathrm{H}_{\mathrm{a}}$ diterima.

Tingginya motivasi belajar siswa dalam pembelajaran biologi tentunya berpengaruh pada peningkatan hasil belajar kognitif biologi siswa, ada pengaruh model pembelajaran scramble dengan media crossword puzzle terhadap hasil belajar biologi siswa. Hasil belajar kognitif pada kelas ekperimen lebih tinggi daripada kelas kontrol. Hal ini dapat dibuktikan dari hasil analisis uji t yang diambil dari nilai rata-rata post-test, maka diperoleh $t_{\text {hitung }} \geq t_{\text {tabel }}$ yaitu $16,58 \geq 2,02$, sehingga hasil pengujian hipotesis dinyatakan $\mathrm{H}_{0}$ ditolak dan $\mathrm{H}_{\mathrm{a}}$ diterima.

Motivasi belajar dan hasil belajar kognitif biologi siswa dengan menggunakan model pembelajaran scramble dengan media crossword puzzle lebih baik daripada menggunakan model pembelajaran konvensional. Maka dari itu, sekolah dapat mengadakan pelatihan kepada guru-guru mengenai berbagai macam strategi pembelajaran. Guru dapat menjadikan model pembelajaran scramble sebagai salah satu alternatif dalam proses pembelajaran dan siswa dapat memanfaatkan sumber belajar dengan baik.

\section{REFERENSI}

Akbar, M.N., Arbi, N.A., \& Mustaqim. (2018). Application of crossword puzzles to increase student's learning outcome on motion system material of biology. International Journal of Multidisciplinary Research and Development, 5(5), 178-183.

Arieska, P.K. \& Herdiani, N. (2018). Pemilihan teknik sampling berdasarkan perhitungan efisiensi relatif. Jurnal Statistika, 6(2). 166171.

https://doi.org/10.26714/jsunimus.6.2.2018.\%2 $5 p$ 
Arofah, S.J.N. \& Efendi, M. (2015). Cross-game puzzle media for learning english of deaf students. Jurnal P3LB, 2(1), 39-43.

Bailang, I. (2017). Penerapan model pembelajaran kooperatif tipe scramble terhadap hasil belajar matematika. Jurnal Sains, Matematika \& Edukasi, 5(2), 132.

Hadi, R., Syafruddin, D., \& Wahyuni, F.R.E. (2017). Pengaruh model pembelajaran scramble terhadap hasil belajar siswa materi kingdom animalia di kelas X Sekolah Menengah Atas Negeri 2 Sintang. Jurnal Pendidikan Biologi, 2(1), 26-31.

Hafsah, N. (2017). Perbandingan Metode Pembelajaran Kooperatif Tipe Scramble Dan Metode Make-A Match Terhadap Hasil Belajar Biologi Siswa Kelas XI IPA SMA Negeri 2 Takalar [Tesis]. UIN Alauddin Makassar.

Hasan, A.M., (2017). Strategi Belajar Mengajar Biologi. UNG Press.

Huda, M. (2018). Model-model pengajaran dan pembelajaran: Isu-isu metodis dan paradigmatis. Pustaka Pelajar.

Kementerian Agama RI. (2015). Al-Qur'an dan Terjemahan Lajnah Pentashihan Mushaf AlQur'an Kementerian Agama RI. Dharma Art.

Majid, A. (2017). Strategi Pembelajaran. Remaja Rosdakarya.

Marzuki \& Khanifah, S. (2016). Pendidikan ideal perspektif Tagore dan Ki Hajar Dewantara dalam pembentukan karakter peserta didik. Jurnal Civics, 13(2), 172-181. https://doi.org/10.21831/civics.v13i2.12740

Mukrimah, S.S. (2014). 53 metode belajar dan pembelajaran. Universitas Pendidikan Indonesia.

Nurmawati. (2016). Evaluasi Pendidikan Islam. Perdana Mulya Sarana.

Parinding, M. \& Lumbu, A, (2015). Pengaruh penerapan model pembelajaran kooperatif tipe scramble terhadap minat dan hasil belajar biologi pada siswa kelas XI IPA SMA Negeri 1 Manokwari. Jurnal Ilmu Pendidikan Indonesia, 3(2), 32-38.

https://doi.org/10.31957/jipi.v3i2.354

Rosady, F. (2017). Pengaruh model pembelajaran teams game tournament (TGT) berbasis teka-teki silang terhadap hasil belajar kognitif siswa pada materi sistem pencernaan di SMP N 2 Kelam Permai. Jurnal Pendidikan Biologi, 2(1), 9-17.
Sinaga, I.L.A., Sinambela, M., \& Rosida. (2017). Hubungan motivasi belajar siswa dengan hasil belajar biologi pada materi pokok sistem ekskresi manusia kelas XI MIA SMA Negeri 16 Medan. Jurnal Pelita Pendidikan, 5(2), 1-8.

https://doi.org/10.24114/jpp.v5i2.7543

Somartono \& Normalina. (2015). Motivasi dan hasil belajar dalam siswa pembelajaran matematika dengan menggunakan model pembelajaran kooperatif tipe scramble di SMP. Jurnal Pendidikan Matematika, 3(1), 84-91.

Syafaruddin, Asrul, \& Mesiono. (2016). Inovasi pendidikan: Suatu analisis terhadap kebijakan baru pendidikan. Perdana Publishing.

Tanjung, I.F. (2016). Guru dan strategi inkuiri dalam pembelajaran biologi. Jurnal Tarbiyah, 23(1), 64-82.

Tanjung, I.F. (2018). Strategi pembelajaran biologi. Widya Puspita. 